\title{
ANALISIS JALUR (PATH ANALYSIS) DER TERHADAP RETURN SAHAM ')
}

\author{
Siti Maisaroh \\ Mahasiswa Program Studi S1 Ekonomi Islam-Fakultas Ekonomi dan Bisnis-Universitas Airlangga \\ Email: may.ctea@gmail.com \\ Imron Mawardi \\ Departemen Ekonomi Syariah-Fakultas Ekonomi dan Bisnis-Universitas Airlangga \\ Email: ronmawardi@yahoo.co.id
}

\begin{abstract}
:
A source of company funds reflected through foreign capital and their own capital that was worn by the company. Jakarta islamic index is one stock index in indonesia who calculates an average price index stock for a stocks which satisfies the criteria of investment in by islamic syariah. Public companies of JII having financial concerns about the limitation debt, that is debt ratio. This limitation used to review whether there is significant influence of the debt and profitability to return of manufacturing firm in JII. The research approach that used is quantitative analysis by technical lines ( paths analysis ). The exogent variable that used is DER, while the endogent variable is return of stock and the intervening variable is ROE. The result obtained that DER influence significanly to $R O E$, $R O E$ has no significant influence on Return of stock, and DER has no significant influence on return of stock.
\end{abstract}

Keywords : Capital Structure, Profitability, Return of stock, Debt to Equity Ratio, Return On Equity

\section{PENDAHULUAN}

\section{Latar Belakang}

Perkembangan perekonomian terutama di Indonesia menunjukkan kemajuan yang luar biasa ditinjau dari komposisi PDB nya. Indonesia berubah dari negara yang perekonomiannya sangat bergantung pada pertanian menjadi negara yang perekonomiannya lebih seimbang, di mana sektor manufaktur (sejenis industri) kini lebih dominan daripada sektor pertanian. Hal tersebut melatar belakangi munculnya banyak perusahaan yang bergerak di berbagai sektor ekonomi. Hal ini membuat persaingan antar perusahaan semakin ketat dalam mengembangkan dan memajukan perusahaannya. Namun pada umumnya tujuan perusahaan yaitu memaksimalkan kesejahteraan pemilik, melalui peningkatan nilai perusahaan
(Moeljadi, 2006: 25). Tujuan normatif tersebut dapat diwujudkan dengan memaksimumkan nilai pasar perusahaan (market value of the firm).

Memaksimumkan nilai pasar perusahaan sama dengan memaksimumkan harga pasar saham, bagi perusahaan yang sudah go public. Dilihat dari sudut pandang manajemen keuangan, peningkatan nilai perusahaan diartikan dengan memaksimalkan kesejahteraan pemilik (shareholder) melalui kebijakan investasi, keputusan pendanaan, dan keputusan dividen yang tercermin dalam harga saham di pasar modal. Berdasarkan pandangan Islam, seorang muslim yang bergerak dalam bisnis harus sesuai dengan prinsip syar'i sehingga mereka dapat terhindar dari perbuatan dosa. Hal ini tidak terkecuali dalam transaksi saham. Dalam melakukan

\footnotetext{
1) Jurnal ini merupakan bagian dari skripsi yang ditulis oleh Siti Maisaroh 041114049 yang diuji pada 10
} Agustus 2015 
transaksi saham, seorang muslim harus pandai memilah dan memilih saham-saham mana saja yang sesuai prinsip dasar Islam. Dan untuk itu, salah satu indeks saham yang sesuai dengan syariah Islam, dimana saham-saham yang berada di dalamnya merupakan saham terpilih yang sesuai dengan syariah Islam telah dibentuk di Indonesia. Di BEI (Bursa Efek Indonesia) sekarang terdapat beberapa penilaian index saham syariah yaitu JII (Jakarta Islamic Index), dan juga ISSI (Indeks Saham Syariah Indonesia).

Salah satu upaya pengembangan pasar modal syariah, PT Bursa Efek Jakarta (BEJ) bersama dengan PT Danareksa Invesment Management (DIM) meluncurkan indeks saham yang dibuat berdasarkan syariah Islam, yaitu Jakarta Islamic Index (JII). Jakarta Islamic Index terdiri dari beberapa jenis saham yang dipilih dari saham-saham yang sesuai dengan syariah Islam. Jakarta Islamic Index dimaksudkan untuk digunakan sebagai tolak ukur (benchmark) untuk mengukur kinerja suatu investasi pada saham dengan basis syariah.

Kinerja perusahaan mencakup kinerja kevangan dan kinerja non keuangan. Dimana salah satu cara untuk mengukur kinerja kevangan dari perspektif kevangan adalah dengan menilai struktur modal perusahaan. Struktur modal sangat penting bagi perusahaan karena menyangkut kebijakan penggunaan sumber dana yang paling menguntungkan. Struktur modal (capital structure) berkaitan dengan pembelanjaan jangka panjang suatu perusahaan yang diukur dengan perbandingan utang jangka panjang dengan modal sendiri. Teori struktur modal menjelaskan apakah kebijakan pembelanjaan jangka panjang dapat mempengaruhi nilai perusahaan, biaya modal perusahaan dan harga pasar saham perusahaan.

Struktur modal dalam penelitian ini diproyeksikan dengan Debt to Equity Ratio (DER). Dimana Debt to Equity Ratio (DER) adalah rasio yang menunjukkan perbandingan antara hutang yang diberikan oleh para kreditur dengan jumlah modal sendiri yang diberikan oleh pemilik perusahaan. Rasio ini menunjukkan proporsi penggunaan hutang dibandngkan modal sendiri untuk membiayai aktivitas perusahaan. Purwitasari (2013) mengartikan profitabilitas sebagai "Kemampuan perusahaan memperoleh laba dalam hubungan dengan penjualan total asset maupun modal sendiri". Rasio profitabilitas terdiri atas Profit Margin, Basic Earning Power, Return On Assets, dan Return On Equity. Rasio profitabilitas akan memberikan gambaran tentang tingkat efektifitas pengelolaan perusahaan. Semakin besar rasio, akan semakin baik, karena kemakmuran pemilik perusahaan meningkat dengan semakin besarnya profitabilitas.

Penelitian ini juga akan dilakukan analisis mengenai tingkat pengembalian, yang akan dilihat dari return saham. Return merupakan hasil yang diperoleh dari investasi, return dapat berupa realisasi yang 
sudah terjadi atau return ekspektasi yang belum terjadi tetapi yang diharapkan akan terjadi dimasa datang. Berdasarkan latar belakang tersebut serta alasan pentingnya struktur modal bagi suatu perusahaan, maka peneliti tertarik untuk mengambil judul: "Pengaruh Struktur Modal Terhadap Profitabilitas Dan Return Saham Perusahaan Manufaktur Yang Terdaftar Di JII (Jakarta Islamic Index) Tahun 2009-2013."

\section{Rumusan Masalah}

Berdasarkan uraian latar belakang diatas, maka rumusan masalah dalam penelitian ini adalah:

1. Apakah struktur modal berpengaruh terhadap profitabilitas perusahaan manufaktur yang listing di JII tahun 2009 - 2013 ?

2. Apakah profitabilitas berpengaruh terhadap return saham perusahaan manufaktur yang listing di JII tahun $2009-2013$ ?

3. Apakah struktur modal berpengaruh terhadap return saham perusahaan manufaktur yang listing di JII tahun $2009-2013 ?$

\section{Tujuan Penelitian}

1. Mengetahui seberapa besar pengaruh signifikan struktur modal terhadap profitabilitas perusahaan manufaktur yang listing di Jll tahun 2009 - 2013.

2. Mengetahui seberapa besar pengaruh signifikan profitabilitas terhadap return saham perusahaan manufaktur yang listing di JII tahun 2009 - 2013.

3. Mengetahui seberapa besar pengaruh signifikan struktur modal terhadap return saham perusahaan manufaktur yang listing di Jll tahun 2009 - 2013.

\section{LANDASAN TEORI DAN PENGEMBANGAN HIPOTESIS}

Berdasarkan Keputusan Menteri Kevangan RI No 1548/KMK/90, tentang Peraturan Pasar Modal, pengertian pasar modal secara umum adalah suatu sistem keuangan yang terorganisasi, termasuk didalamnya adalah bank-bank komersial dan semua lembaga perantara di bidang keuangan, serta keseluruhan surat-surat berharga yang beredar.

Investasi pada hakikatnya merupakan penempatan sejumlah dana pada saat ini dengan harapan untuk memperoleh keuntungan di masa mendatang (Halim, 2003: 2). Investasi sebagai penundaan konsumsi sekarang untuk digunakan di dalam produksi yang efisien selama periode waktu tertentu (Jogiyanto, 2003: 5).

Struktur modal adalah kombinasi pendanaan perusahaan. Semua itu ada pada bagian kanan dari neraca, yang menandakan bahwa sumber pendanaan sebagian besar berasal dari luar perusahaan. Struktur modal terdiri dari utang jangka panjang, saham preferen, dan kepemilikan biasa (saham biasa) (Saragih, 2005:135).

Profitabilitas menurut Riyanto (1998) adalah kemampuan perusahaan untuk menghasilkan laba selama periode tertentu. Profitabilitas suatu perusahaan diukur dengan kesuksesan perusahaan dan kemampuan menggunakan aktivanya secara produktif. Dengan demikian 
profitabilitas suatu perusahaan dapat diketahui dengan membandingkan antara laba yang diperoleh dalam suatu periode dengan jumlah aktiva atau jumlah modal perusahaan tersebut. Profitabilitas dapat diukur dengan menggunakan rasio profitabilitas yaitu rasio-rasio yang menunjukkan hasil akhir dari sejumlah kebijaksanaan dan keputusan-keputusan. ROE = EAT (laba bersih setelah pajak) Common Equity (modal saham)

Return merupakan hasil yang diperoleh dari investasi, return dapat berupa realisasi yang sudah terjadi atau return ekspektasi yang belum terjadi tetapi yang diharapkan akan terjadi dimasa datang. Return realisasi (realized return) merupakan return yang telah terjadi dan dihitung berdasarkan data historis. Return realisasi itu dapat digunakan sebagai salah satu untuk mengukur kinerja perusahaan (Jogiyanto, 2003: 109). Return (kembalian) adalah tingkat keuntungan yang dinikmati oleh pemodal atas suatu investasi yang dilakukannya. Tanpa adanya tingkat keuntungan yang dinikmati dari suatu investasi, tentunya investor (pemodal) tidak akan melakukan investasi.

$\mathrm{R} t=\mathrm{P} \dagger-\mathrm{Po}$

$$
\text { Po }
$$

Keterangan :

$$
\begin{aligned}
& \mathrm{Rt}=\text { return aktual saham i periode } \dagger \\
& \mathrm{Pt}=\text { harga saham i periode } \dagger \\
& \mathrm{Po}=\text { harga saham i periode } \dagger-1
\end{aligned}
$$

Kebijakan perusahaan mendapatkan modal pinjaman dari luar ditinjau dari bidang manajemen keuangan, merupakan penerapan kebijakan financial leverage atau juga disebut dengan "pengungkit keuangan". Dimana perusahaan membiayai kegitannya (operasional) dengan menggunakan modal pinjaman serta menanggung suatu beban tetap yang bertujuan untuk meningkatkan laba per lembar saham. Namun penggunaan modal pinjaman dilakukan apabila kebutuhan pendanaan tidak dapat lagi dipenuhi dengan menggunakan modal sendiri atau kurang tersedianya modal sendiri. Penggunaan modal pinjaman tersebut akan mempengaruhi tingkat risiko yang dihadapi dan juga biaya modal yang ditanggung perusahaan. Menurut Brigham dan Houston, leverage keuangan (financial leverage) merupakan suatu ukuran yang menunjukkan sampai sejauh mana sekuritas berpenghasilan tetap (utang dan saham preferen) digunakan dalam stuktur modal perusahaan.

Seperti yang diungkapkan oleh Husnan (2001: 315) dalam analisis fundamental, yaitu " Analisis fundamental mencoba memperkirakan harga saham dimasa yang akan datang dengan (i) mengestime nilai faktor-faktor fundamental yang mempengaruhi harga saham dimasa yang akan datang, dan (ii) menetapkan hubungan variabel-variabel tersebut sehingga diperoleh taksiran harga saham. Model analisis fundamental sering disebut sebagai share price forecasting model, dan sering digunakan dalam berbagai pelatihan analisis sekuritas." Perhitungan rasio profitabilitas yaitu ROE juga termasuk 
dalam salah satu analisis fundamental, karena dengan mengetahui nilai ROE maka secara tidak langsung juga akan diketahui perkiraan harga saham di pasar sehingga investor dapat memperkirakan berapa besar return yang akan didapat dari saham tersebut.

Penelitian ini mengukur struktur modal dengan rasio DER (Debt to Equity Ratio). Dalam hasil penelitian Ulupui (2009), variabel debt to equity ratio, menunjukkan hasil yang positif tetapi tidak signifikan terhadap return saham. Jika dilihat dari hasil tersebut, mengindikasikan bahwa rasio utang tidak menyebabkan perubahan return saham satu tahun ke depan. Meskipun hasilnya tidak signifikan, bukan berarti bahwa investor dapat mengabaikan rasio utang suatu perusahaan. Sering kali kondisi financial distress yang dihadapi perusahaan disebabkan oleh kegagalan dalam membayar utang.

Struktur modal dan profitabilitas memiliki hubungan yang tidak dapat diabaikan, dimana keduanya memiliki hubungan yang saling mempengaruhi satu dan lainnya. Beberapa penelitian sebelumnya telah membahas mengenai struktur modal, profitabilitas dan juga return saham, diantaranya yaitu penelitian yang dilakukan oleh Purwitasari pada tahun 2013, yang menganalisis pengaruh struktur modal terhadap profitabilitas perusahaan manufaktur yang listing di BEI. Hasil dari penelitian tersebut yaitu strukur modal berpengaruh secara positif dan signifikan terhadap profitabilitas perusahaan manufaktur yang listing di BEl tahun 20092011.

Berdasarkan rumusan masalah, tujuan penelitian, dan landasan teori, maka dalam penelitian ini diajukan hipotesis sebagai berikut:

Hipotesis 1: struktur modal (DER) berpengaruh signifikan terhadap profitabilitas (ROE) perusahaan manufaktur yang terdaftar di JII Tahun 2009 - 2013.

Hipotesis 2: profitabilitas (ROE) berpengaruh signifikan terhadap return saham perusahaan manufaktur yang terdaftar di JII Tahun 2009 - 2013.

Hipotesis 3: struktur modal (DER) berpengaruh signifikan terhadap return saham perusahaan manufaktur yang terdaftar di JII tahun 2009 - 2013.

Sesuai dengan tinjauan teoritis dan pengujian hipotesis di atas maka dapat dibuat model dalam bentuk persamaan struktural sebagai berikut:

$R O E=\rho X Y_{1} D E R+e_{1}$

Return Saham $=\rho X Y_{2} D E R+\rho Y_{1} Y_{2} R O E+e_{2}$ Dimana :

$X=$ struktur modal (DER)

$Y_{1}=R O E$

$Y_{2}=$ Return Saham

$e_{1}=$ variabel lain yang mempengaruhi $Y_{1}$ $\mathrm{e}_{2}=$ variabel lain yang mempengaruhi $Y_{2}$ $\rho ; X ; Y_{1,2}=$ Koefisien jalur $X$ terhadap $Y_{1,2}$

\section{METODE PENELITIAN}

\section{Pendekatan Penelitian}

Berdasarkan variabel-variabel yang telah ditentukan dan model penelitian yang telah disusun pada bab sebelumnya, maka penelitian ini menggunakan pendekatan 
kuantitatif untuk menjawab rumusan masalah. Pendekatan kuantitatif adalah pendekatan ilmiah terhadap pengambilan keputusan manajerial dan ekonomi (Kuncoro, 2011:3).

\section{Identifikasi Penelitian}

Variabel endogen dalam penelitian ini yaitu return saham. Sedangkan variabel eksogen dalam penelitian ini yaitu struktur modal dengan rasio DER (Debt to Equity Ratio) dan yang menjadi variabel intervening dalam penelitian ini adalah profitabilitas yang diukur dengan rasio ROE (Return On Equity Ratio). Data pada penelitian ini didapatkan dari web resmi BEl, ICMD, serta literatur lain yang terdapat data saham yang bersangkutan.

\section{Definisi Operasional Variabel}

1. Debt to equity ratio ini mengukur proporsi besar kecilnya penggunaan utang dibandingkan dengan modal sendiri perusahaan. Rasio DER disini didapat dari laporan keuangan yang dikeluarkan oleh perusahaan per 31 Desember dengan periode penelitian 2009 sampai dengan 2013. DER merupakan perbandingan antara total utang dengan ekuitas yang dimiliki perusahaan.

2. ROE menunjukkan kemampuan perusahaan untuk menghasilkan laba setelah pajak dengan menggunakan modal sendiri yang dimiliki perusahaan (Sudana, 2009: 26). Rasio ini didapat dari laporan kevangan perusahaan yang dipublikasikan dan ditulis per 31 Desember pada periode penelitian 2009 sampai 2013.
3. Return (tingkat pengembalian) adalah tingkat keuntungan yang dinikmati oleh pemodal atas suatu investasi yang dilakukannya. Dalam penelitian ini, return saham didapat dari lampiran return saham perusahaan yang diteliti dan dipublikasikan melalui website ICMD dengan periode penelitian 2009 sampai 2013. Dimana perhitungannya yaitu dengan membandingkan harga saham periode $\dagger$ dikurangi dengan harga saham periode t- 1 dibandingkan dengan harga saham periode $\mathrm{t}-1$.

\section{Teknik Analisis data}

Penelitian yang dilakukan ini merupakan penelitian kuantitatif. Teknik analisis dalam penelitian ini adalah path analysis (analisis jalur) untuk mengetahui dan menganalisis pengaruh dari variabelvariabel independen terhadap variabel dependen. Path analysis atau analisis jalur bertujuan untuk menerangkan akibat langsung dan tidak langsung seperangkat variabel bebas dengan seperangkat variabel terikat (Sanusi, 2011: 156).

\section{HASIL DAN PEMBAHASAN \\ Uji Normalitas}

Hasil uji normalitas dengan menggunakan metode One Sample Kolmogorov Smirnov Test, data dapat dikatakan terdistribusi secara normal apabila nilai Kolmogorov-Smirnov $Z$ menunjukkan angka yang lebih besar dari nilai $\alpha$ yaitu 0,05 (5\%). Hasil dari uji normalitas dalam penelitian ini ditunjukkan oleh tabel berikut : 
Tabel 1.

Hasil Uji Normalitas

One-Sample Kolmogorov-Smirnov Test

\begin{tabular}{|c|c|c|c|c|}
\hline & & DER & ROE & $\begin{array}{c}\text { Retum_Saha } \\
\mathrm{m}\end{array}$ \\
\hline \multicolumn{2}{|l|}{$\mathrm{N}$} & 55 & 55 & 55 \\
\hline \multirow[t]{2}{*}{ Nomal Parameters ${ }^{\mathrm{a}}$} & Mean & .7189 & 42.1573 & 19.8702 \\
\hline & Std. Deviation & .48145 & $3.24708 \mathrm{E}$ & 49.99605 \\
\hline Most Extreme & Absolute & .159 & .222 & .192 \\
\hline \multirow[t]{2}{*}{ Differences } & Positive & .159 & .222 & .192 \\
\hline & Negative & -119 & -.156 & -.165 \\
\hline \multicolumn{2}{|c|}{ Kolmogorov-SmimovZ } & 1.179 & 1.646 & 1.423 \\
\hline \multicolumn{2}{|l|}{ Asymp. Sig. (2-tailed) } & .124 & .009 & .035 \\
\hline
\end{tabular}

Sumber: hasil pengolahan data

Data dikatakan terdistribusi normal apabila angka Kolmogorov-Smirnov Z > 0,05 , sebaliknya apabila angka tersebut < 0,05 maka dikatakan bahwa data tidak terdistribusi normal. Berdasarkan hasil uji normalitas pada tabel 4.5 di atas dapat diinterpretasikan sebagai berikut:

1. Kolmogorov-Smirnov $Z$ pada DER memiliki nilai sebesar 1,179>0,05, hal ini menunjukkan bahwa data DER terdistribusi secara normal.

2. Kolmogorov-Smirnov $Z$ pada ROE memiliki nilai sebesar 1,646>0,05, hal ini menunjukkan bahwa data ROE terdistribusi secara normal.

3. Kolmogorov-Smirnov $\mathrm{Z}$ pada return saham memiliki nilai sebesar 1,423 > 0,05, hal ini menunjukkan bahwa data return saham terdistribusi secara normal.

\section{Uji Multikolinieritas}

Multikolinieritas adalah adanya hubungan linier yang signifikan antara variabel independen dalam regresi. Untuk mendeteksi adanya multikolinieritas pada model regresi dapat diukur dengan nilai Variance Inflation Factor (VIF). Multikolinieritas terjadi apabila nilai VIF>10.

Tabel 2.

Hasil Uji Multikolinieritas

Uji.1.ultitiolinearitas

Coefficientss

\begin{tabular}{|c|c|c|c|c|c|c|c|}
\hline \multirow[b]{2}{*}{ Model } & \multicolumn{2}{|c|}{$\begin{array}{l}\text { Unstandardired } \\
\text { Coefficicents }\end{array}$} & \multirow{2}{*}{$\begin{array}{c}\text { Standardized } \\
\text { Coefficicints } \\
\text { Beta } \\
\end{array}$} & \multirow[b]{2}{*}{ I } & \multirow[b]{2}{*}{ Sigg. } & \multicolumn{2}{|c|}{ Collinearity Statisitics } \\
\hline & B & Std. Error & & & & Tolerance & $\mathrm{VIF}$ \\
\hline (Constant) & 19.613 & 13.264 & & 1.479 & .145 & & \\
\hline DER & .128 .822 & 15.786 & .123 & .812 & .420 & .815 & 1.228 \\
\hline ROE & .225 & .234 & .146 & .960 & 341 & .815 & 1.228 \\
\hline
\end{tabular}

Sumber: data SPSS (diolah)

Berdasarkan hasil uji multikolinearitas pada tabel 4.6 tersebut menunjukkan bahwa nilai VIF nya adalah 1,228, dimana 1,228 masih berada disekitar angka 1 dan $1,228<10$ dan juga dari nilai Tolerance-nya yaitu 0,815 yang mendekati 1 , maka hal ini menunjukkan bahwa tidak terjadi gejala multikolinearitas

\section{Pengujian Hipotesis}

H1: struktur modal (DER) berpengaruh signifikan terhadap profitabilitas (ROE) perusahaan manufaktur yang terdaftar di JII Tahun 2009 - 2013.

Pengujian $t$-value variabel $X$ (DER) terhadap variabel $Y 1$ (ROE) pada hasil perhitungan SPSS pada tabel 4.8 diperoleh nilai sebesar 3,473 . Nilai signifikansi tersebut lebih besar dari nilai t-tabel yaitu 1,67, sehingga hipotesis pertama yang menyatakan struktur modal (DER) berpengaruh signifikan terhadap profitabilitas (ROE) perusahaan dapat 
diterima. T-value pada variabel $X$ (DER) menunjukkan nilai yang positif, artinya bentuk pengaruh yang diberikan oleh variabel $X$ (DER) terhadap variabel $Y 1$ (ROE) adalah searah. Jadi kesimpulannya adalah DER berpengaruh secara signifikan dan searah terhadap ROE.

H2: profitabilitas (ROE) berpengaruh signifikan terhadap return saham perusahaan manufaktur yang terdaftar di JII Tahun 2009 - 2013.

Hasil Pengujian t-value variabel Y1 (ROE) terhadap variabel Y2 (return saham) berdasarkan tabel 4.11 diperoleh hasil 0,960. Nilai signifikansi tersebut lebih kecil dari nilai t-tabel 1,67, sehingga hipotesis kedua yang menyatakan profitabilitas (ROE) berpengaruh signifikan terhadap return saham perusahaan tidak dapat diterima kebenarannya. T-value pada variabel Y2 (return saham) menunjukkan nilai yang positif, artinya bentuk pengaruh yang diberikan oleh variabel $Y 1$ terhadap variabel Y2 adalah searah. Jadi kesimpulannya adalah, profitabilitas (ROE) berpengaruh tetapi tidak signifikan terhadap return saham dengan arah yang positif (searah).

H3: struktur modal (DER) berpengaruh signifikan terhadap return saham perusahaan manufaktur yang terdaftar di JII tahun 2009 - 2013.

Hasil Pengujian $t$-value variabel $X$ (DER) terhadap variabel Y2 (return saham) berdasarkan tabel 4.11 diperoleh hasil 0,812. Nilai signifikansi tersebut lebih kecil dari nilai t-tabel 1,67, sehingga hipotesis ketiga yang menyatakan struktur modal (DER) berpengaruh signifikan terhadap return saham perusahaan dapat diterima kebenarannya. T-value pada variabel Y2 (return saham) menunjukkan nilai yang negatif, artinya bentuk pengaruh yang diberikan oleh variabel $X$ terhadap variabel Y2 adalah berlawanan arah. Jadi kesimpulannya adalah, struktur modal (DER) berpengaruh tidak signifikan terhadap return saham dengan arah yang berlawanan.

\section{Pembahasan}

\section{Pengaruh Struktur Modal terhadap Profitabilitas Perusahaan}

Berdasarkan hasil pengujian nilai t-value struktur modal (DER) terhadap profitabilitas (ROE) menunjukkan hasil bahwa t-value DER lebih besar dari t-tabel nya $(3,473>1,67)$. Hal tersebut berarti bahwa pengaruh DER terhadap ROE adalah signifikan dengan arah yang positif. Artinya, apabila terjadi kenaikan penggunaan utang dalam perusahaan, maka profitabilitas perusahaan juga ikut meningkat. Hal ini mendukung hasil penelitian yang dilakukan oleh Nurhansah (2012), menunjukkan bahwa DER berpengaruh signifikan terhadap ROE. Semakin tinggi proporsi utang maka akan semakin tinggi nilai perusahaan yang dilihat dari profit yang diperolehnya, namun pada titik tertentu peningkatan utang akan menurunkan nilai perusahaan karena manfaat yang diperoleh dari penggunaan utang jauh lebih kecil bila dibandingkan dengan biaya yang ditimbulkan dari penerbitan utang. 
Pengaruh Profitabilitas terhadap Return Saham

Hasil penelitian ini menunjukkan bahwa rasio profitabilitas memiliki pengaruh yang negatif dan tidak signifikan terhadap return saham. Hal ini menunjukkan bahwa tidak selamanya investor lebih mementingkan penilaian terhadap suatu perusahaan berdasarkan aspek fundamentalnya saja. Karena dalam penelitian ini analisis fundamental tidak cocok untuk diterapkan dalam penilaian harga saham yang kemudian menentukan return saham yang diterima oleh pemegang saham atau investor. Hal ini menandakan bahwa profitabilitas suatu perusahaan tidak selalu menjadi penilaian utama bagi beberapa investor dalam membuat keputusan investasinya. Karena terdapat beberapa faktor lain diluar penelitian yang juga bisa mempengaruhi besar kecilnya return saham yang diterima oleh pemegang saham. Faktor tersebut seperti yang telah disebutkan di atas yaitu faktor internal dan faktor eksternal. Rasio profitabilitas memang memberikan pengaruh terhadap return saham, namun kontribusinya hanya sebesar $14,6 \%$, hal ini menunjukkan bahwa faktorfaktor lain diluar penelitian memiliki kontribusi pengaruh yang lebih besar terhadap perubahan return saham.

\section{Pengaruh Struktur Modal terhadap Return Saham}

Menurut Brigham (1998: 298) dalam teori trade off, setiap perusahaan harus menetapkan target struktur modalnya, yaitu pada posisi keseimbangan biaya dan keuntungan marginal dari pendanaan dengan utang, sebab pada posisi itu nilai perusahaan menjadi maksimum. Berdasarkan teori tersebut, menggunakan semakin banyak utang berarti memperbesar resiko yang ditanggung oleh pemegang saham dan juga memperkecil tingkat pengembalian yang diharapkan sehingga potensial mengurangi return saham. Selain itu, alasan lain yang menyebabkan pengaruh DER terhadap return saham dalam penelitian ini bersifat tidak signifikan dan negatif dapat disebabkan oleh beberapa hal. Salah satunya yaitu karena faktor-faktor yang mempengaruhi return saham bukan hanya dari DER, tetapi banyak variabel-variabel lain yang mempengaruhi return saham diluar variabel-variabel yang digunakan dalam penelitian.

\section{v. SIMPULAN}

Berdasarkan data dan hasil analisis yang telah dilakukan maka dapat diambil kesimpulan sebagai berikut:

1. Struktur modal yang diukur dengan debt to equity ratio berpengaruh signifikan dengan arah positif terhadap profitabilitas yang diukur dengan rasio ROE. Ini memperkuat teori leverage, bahwa utang perusahaan yang banyak justru direspon secara positif oleh investor disebabkan semakin tinggi proporsi utang maka akan semakin tinggi nilai perusahaan yang dilihat dari profit yang diperolehnya, karena utang berfungsi sebagai pengungkit, namun pada titik tertentu 
peningkatan utang akan menurunkan nilai perusahaan karena manfaat yang diperoleh dari penggunaan utang jauh lebih kecil bila dibandingkan dengan biaya yang ditimbulkan dari penerbitan utang.

2. Tingkat profitabilitas (ROE) berpengaruh tidak signifikan terhadap return saham. Pengaruh yang tidak signifikan ini dapat terjadi karena selain variabel dalam penelitian (profitabilitas), masih banyak variabelvariabel lain yang mempengaruhi tingkat return saham. Profitabilitas merupakan faktor internal dari perusahaan, sedangkan faktor-faktor yang mempengaruhi return saham itu ada 2 yaitu faktor internal dan juga faktor eksternal. Berdasarkan kasus penelitian ini dapat disimpulkan bahwa faktor eksternal berpengaruh lebih besar terhadap return saham dibandingkan dengan faktor internalnya.

3. Hasil penelitian ini menunjukkan bahwa DER berpengaruh tidak signifikan terhadap return saham. Hal ini dikarenakan faktor-faktor yang mempengaruhi return saham diluar faktor fundamental perusahaan sangat banyak. Penelitian ini menunjukkan bahwa faktor eksternal dari perusahaan memberikan pengaruh yang lebih besar dibandingkan faktor internal perusahaan. Faktor-faktor eksternal perusahaan itu bisa berupa peraturan yang ada, faktor psikologis pasar, maupun resesi ekonomi.

\section{DAFTAR PUSTAKA}

Eugene F, Brigham dan Joel F, Houston. 1998. Manajemen Keuangan. Jakarta: Erlangga.

Ghozali, Imam. 2009. Aplikasi Analisis Multivariate dengan Program SPSS. Cetakan ke IV. Semarang: Badan Penerbit UNDIP.

Ginting sugihen, Syafruddin. 2003. Pengaruh Struktur Modal Terhadap Produktivitas Aktiva Dan Kinerja Keuangan Serta Nilai Perusahaan Industri Manufaktur Terbuka Di Indonesia. Disertasi tidak diterbitkan. Surabaya Program Pasca Sarjana Universitas Airlangga.

Harmono. 2009. Manajemen Keuangan Berbasis Balanced Scorecard. Jakarta: PT Bumi Aksara.

Husnan, Suad. 2009. Dasar-dasar Teori Portofolio Dan Analisis Sekuritas. Yogyakarta: UPP STIM YKPN. Jogiyanto. 2003. Teori Portofolio dan Analisis Investasi. Yogyakarta: BPFE.

Kartika, Andi. 2009. Faktor-faktor yang Mempengaruhi Struktur Modal pada Perusahaan manufaktur yang Go Public di BEl. Dinamika Keuangan dan Perbankan, 1 (2): 105-122.

Kuncoro, Mudrajad. 2011. Metode Kuantitatif: Teori Dan Aplikasi Untuk Bisnis Dan Ekonomi. Yogyakarta: UPP STIM YKPN. 
Kusumajaya, Dewa Kadek Oka. 2011. Pengaruh Struktur Modal dan Pertumbuhan perusahaan terhadap Profitabilitas dan Nilai Perusahaan Manufaktur di Bursa Efek Indonesia. Tesis tidak diterbitkan. Denpasar Pascasarjana Universitas Udayana.

Lubis, Suhrawardi K. 2004. Hukum Ekonomi Islam. Jakarta: Sinar Grafika.

Madura, Jeff. 2001. Pengantar Bisnis. Jakarta: Salemba Empat.

Nurhansah. 2012. Pengaruh Struktur Modal terhadap Profitabilitas pada Perusahaan Manufaktur yang Terdaftar di Bursa Efek Indonesia (BEI). IImiah, IV (3): 1-9.

Purwitasari, Elisa. 2013. Analisis Pengaruh Struktur Modal terhadap Profitabilitas.

Skripsi tidak diterbitkan. Semarang Fakultas ekonomika dan Bisnis Universitas Diponegoro.

Salim, Ubud. 2011. Manajemen Kevangan Strategik. Malang: UB Press.

Saragih, D. Ferdinand dkk. 2005. DasarDasar Kevangan Bisnis Teori Dan Aplikasi. Jakarta: PT Elex Media Komputindo.

Setyosari, Punaji. 2010. Metode Penelitian Pendidikan dan Pengembangan. Jakarta: Kencana.

Sudarsono, Heri. 2007. Bank dan Lembaga Kevangan Syariah Deskripsi dan Ilustrasi. Yogyakarta: Ekonisia.

Susilowati, Yeye \& Tri Turyanto. 2011. Reaksi Signal Rasio Profitabilitas dan Rasio Solvabilitas terhadap Return Saham
Perusahaan. Dinamika Keuangan dan Perbankan, 3 (1): 17-37.

Sutedi, Adrian. 2011. Pasar Modal Syariah: Sarana Investasi Kevangan Berdasarkan Prinsip Syariah. Jakarta: Sinar Grafika.

Ulupui. 2009. Analisis Pengaruh Rasio Likuiditas Leverage, Aktivitas, dan Profitabilitas terhadap Return Saham Studi pada Perusahaan Makanan dan Minuman dengan Kategori Industri Barang Konsumsi di BEJ. -.

Vogel, Frank. E \& Hayes, Samuel L. 2007. Hukum Keuangan Islam: Konsep Teori dan Praktik. Bandung: Nusamedia.

Walsh, Ciaran. 2004. Key Manajemen Ratios: rasio-rasio Manajemen Penting penggerak dan pengendali bisnis.edisi ketiga. Jakarta: erlangga.

Zubir, Zalmi. 2013. Manajemen Portofolio: Penerapannya Dalam Investasi Saham. Jakarta: Salemba Empat. 